\title{
Does self-employment really raise job satisfaction? Adaptation and anticipation effects on self-employment and general job changes
}

\author{
Dominik Hanglberger · Joachim Merz
}

Published online: 16 June 2015

(C) Institut für Arbeitsmarkt- und Berufsforschung 2015

\begin{abstract}
Empirical analyses using cross-sectional and panel data found significantly higher levels of job satisfaction for the self-employed than for employees. We argue that by neglecting anticipation and adaptation effects estimates in previous studies might be misleading. To test this, we specify models accounting for anticipation and adaptation to self-employment and general job changes. In contrast to recent literature we find no specific long-term effect of self-employment on job satisfaction. Accounting for anticipation and adaptation to job changes in general, which includes changes between employee jobs, reduces the effect of self-employment on job satisfaction by twothirds. When controlling for anticipation and adaptation to job changes, we find a positive anticipation effect of self-employment and a positive effect of self-employment on job satisfaction in the first years of self-employment. After 3 years, adaptation eliminates the higher satisfaction of being self-employed. According to our results, previous studies overestimate the positive long-term effects of selfemployment on job satisfaction.
\end{abstract}

Keywords Job satisfaction · Self-employment · Hedonic treadmill model · Adaptation - Anticipation · Fixed effects panel estimation - German Socio-Economic Panel (SOEP)

J. Merz $(\bowtie) \cdot$ D. Hanglberger

Research Institute on Professions (FFB), Leuphana University

Lüneburg,

Lüneburg, Germany

e-mail: merz@uni.leuphana.de

D. Hanglberger

Institut des Bewertungsausschusses,

Berlin, Germany
JEL J23 $\cdot$ J $28 \cdot$ J 81

Erhöht eine Selbständigkeit wirklich die Arbeitszufriedenheit? Adaptions- und Antizipationseffekte der Selbständigkeit und genereller Arbeitsplatzwechsel

Zusammenfassung Zahlreiche empirische Analysen, auf Querschnittsdaten oder Paneldaten basierend, kamen zu dem Ergebnis, dass Selbständige ein höheres Niveau an Arbeitszufriedenheit erreichen als abhängig Beschäftigte. In unserem Beitrag untersuchen wir, ob dieses empirische Ergebnis möglicherweise auf die Vernachlässigung von Antizipations- und Adaptionseffekten zurückgeführt werden kann. Um den Sachverhalt empirisch zu überprüfen, spezifizieren wir fixed-effects Regressionsmodelle, die auch Antizipation und Adaption der Arbeitszufriedenheit vor einem Wechsel aus abhängiger Beschäftigung in Selbständigkeit und allgemein bei einem Arbeitsplatzwechsel berücksichtigen. Grundlage für unsere Analyse ist das Sozio-oekonomische Panel (SOEP) der Jahre 1984-2009. Im Gegensatz zur existierenden Literatur findet sich keine positive Langzeitwirkung der Selbständigkeit, wenn Antizipation und Adaption berücksichtigt werden. Werden Antizipation und Adaption bei Arbeitsplatzwechsel im Allgemeinen berücksichtigt, so reduziert sich der Effekt der Selbständigkeit auf die Arbeitszufriedenheit um ca. zwei Drittel. In Modellen, die Antizipation und Adaption an Selbständigkeit und Arbeitsplatzwechsel berücksichtigen, zeigt sich lediglich für die ersten drei Jahre der Selbständigkeit eine höhere Arbeitszufriedenheit. Der positive Effekt der Selbständigkeit nimmt in der Folge jedoch ab und ist für Personen, die 4 oder mehr Jahre selbständig sind, nicht mehr signifikant. Die Ergebnisse verdeutlichen damit, dass bisherige Studien die positive Wirkung der Selb- 
ständigkeit auf die Arbeitszufriedenheit zumindest deutlich überschätzen.

Schlüsselwörter Arbeitszufriedenheit · Selbständige · Hedonic treadmill · Adaption - Antizipation - Fixedeffects Panelschätzungen · Sozio-oekonomisches Panel (SOEP)

\section{Introduction}

The economic and societal importance of the self-employed is unquestioned and is studied in a number of different fields (Parker 2009). Besides other aspects, job satisfaction of the self-employed has been of increasing interest within the last decade. Empirical research on job satisfaction in numerous studies has found that self-employed persons show substantially higher levels of job satisfaction than employees. This result has been consistently confirmed across Europe (e.g. Blanchflower and Oswald 1998; Blanchflower 2000; Benz and Frey 2004, 2008; Clark and Senik 2006) and for the USA and Canada (Kawaguchi 2008; Hundley 2001; Benz and Frey 2004). Among these papers are analyses based on cross sections as well as studies exploiting individual panel data to follow individuals over time.

With our analysis we contribute to the literature by proposing and testing a new explanation for a part of the difference in job satisfaction found in individual panel data between the self-employed and employees: anticipation and adaptation effects.

Adaption and anticipation effects can distort results when estimating regression models. For example, anticipation can distort effect results when individuals tend to be very dissatisfied with their employee work in the years before becoming self-employed. This leads to a comparable higher satisfaction level for the same individuals when self-employed, even when there is no lasting effect of self-employment on job satisfaction. In case of adaptation effects, individuals experience short-term benefits in subjective well-being after becoming self-employed. After some years people become used to being self-employed and satisfaction tends back to the baseline level.

Thus the main questions we address in this paper are:

- Are there anticipation effects which affect the estimation of the effect of self-employment on job satisfaction?

- Is there a long-term positive effect of self-employment on job satisfaction, or does individual satisfaction adapt to self-employment and return to an ex-ante satisfaction level?

The paper is structured as follows: Chap. 2 provides some background on explanations of self-employment job satisfaction. In Chap. 3 we briefly review recent adaptation liter- ature and discuss how neglecting adaptation and anticipation affects estimated coefficients in a fixed effects regression setting. Chapter 4 introduces the data base used for the analysis and Chap. 5 describes our empirical strategy. In Chap. 6 we present a short descriptive analysis and our estimation results, which are summarized and discussed in Chap. 7.

\section{Background and literature}

Empirical analyses on job satisfaction of the self-employed are based on cross sectional as well as on individual longitudinal (panel) data. Whereas panel data allows analysis of the individual's job situation over time, most cross sectional studies have the shortcoming of being based on the comparison of two groups of individuals at one point in time, employees and the self-employed. The reliability of the results depends on the comparability of these subgroups. As Blanchflower and Oswald (1998) note, higher satisfaction levels among the self-employed can also be due to selfselection of optimistic individuals into self-employment; for a review of literature on psychological characteristics of self-employed persons see Brockhaus and Horwitz (1986). The finding that the same individuals on average experience higher job satisfaction when self-employed compared to when working as an employee is mostly interpreted as contradicting the hypothesis of more optimistic/happy people becoming self-employed. ${ }^{1}$

The finding that the self-employed are more satisfied with work is surprising since the self-employed were found, compared to employees, to earn lower wages (Hamilton 2000; Carrington et al. 1996) or face a particular unequal income distribution often with low income (Merz 2007) and longer work hours (Eden 1975 for the United States; Hyytinen and Ruuskanen 2007 for Finland; Merz et al. 2009; Merz and Böhm 2008; and Merz and Burgert 2004a,b for Germany). Hamilton's (2000) analysis shows that the lower wages of the self-employed are not due to negative self-selection processes. Another explanation could be that self-employment offers non-monetary job aspects such as work autonomy

\footnotetext{
${ }^{1}$ A topic in the discussion about "who becomes self-employed" is the influence of personality characteristics. Whereas Blanchflower and Oswald 1998 for example do not rank psychology as a key factor, others like Zhao and Seibert 2006 or recently Caliendo, Fossen and Kritikos 2014 with data of the German Socio-Economic Panel 2000-2009 find that the personality structure (the big five traits and further personal characteristics) plays an important role in determining who becomes and succeeds as an entrepreneur. Though personality characteristics seems to play a role in determining the probability of becoming self-employed in Germany, our focus is not to explain becoming self-employed but rather to explain job satisfaction of the self-employed. Thus, all of these personality characteristics are already part of a self-employed person under investigation; a repeated specification in an appropriate regression model would cause an endogeneity problem and is therefore not further pursued.
} 
which individuals appreciate. Following the theory of compensating wage differentials, the self-employed should earn lower wages if non-monetary gains from self-employment are higher. This view is also supported by Blanchflower and Oswald (1998, p. 46), who assume that "individuals get a non-pecuniary benefit from being their own boss." In line with this argument is the finding by Millán et al. (2011) that the higher job satisfaction of the self-employed compared to employees is attributable to the type of work rather than in terms of job security.

Indeed Benz and Frey $(2004,2008)$ find that the higher level of job satisfaction of the self-employed can largely be explained by the subjective evaluation of work autonomy. This result is consistent with earlier studies by Eden (1975) and Hundley (2001). Benz and Frey's (2004) analysis is based on cross-sectional data taken from the International Social Survey Program 1997. Using German, British, and Swiss individual panel data and accounting for unobserved, time constant, individual heterogeneity, Benz and Frey (2008) confirm the previous cross sectional findings. The authors interpret this result as support for a concept called procedural utility, where "procedural utility means that people do not only care about instrumental outcomes, as is usually assumed in economics, but also value the processes and conditions leading to outcomes" (Benz and Frey 2004, p. 98). An introduction to the concept of procedural utility can be found in Benz and Frey (2008).

Based on two results, first the result that the selfemployed are more satisfied even when controlling for personality and, second, the result that differences disappear when controlling for procedural aspects, Benz and Frey (2008) conclude that differences in job satisfaction between the self-employed and employees can be explained by procedural utility, which is higher for self-employment due to higher levels of work autonomy. Benz and Frey do not explicitly mention whether they consider procedural utility as a permanently experienced utility and thus an effect which is not exposed to adaptation. It seems that this assumption is made implicitly.

In view of the approach chosen by Benz and Frey, it should be further remarked that the practice of using subjective variables as independent variables to explain other subjective evaluations is questionable. It might be that individuals who are satisfied with their job or optimistic in general tend to rate all aspects of a job more positively, independent of the objective job situation, thus reversing causality. For a short discussion of this problem see Hamermesh (2004). An analysis by Hanglberger (2011a), based on data for 31 European countries taken from the European Working Conditions Survey (EWCS), uses objective measures of work autonomy and finds large country differences for the effects of autonomy on employee job satisfaction. Whereas a remarkable and significant effect is found for countries with high welfare levels (UK, Ireland, Scandinavia and Continental Europe), no effect was found for Southern and Eastern European countries and Turkey.

Another explanation of differences in job satisfaction is suggested by Blanchflower and Oswald (1998) and Blanchflower et al. (2001). Both studies find that in surveys the rate of individuals who state that they would prefer to be self-employed to working as an employee is far higher than the actual rate of self-employment. The authors argue that differences in job satisfaction might be due to capital constraints for becoming self-employed. Capital constraints imply that only a small percentage of individuals who prefer self-employment can afford to do so. The group of employees therefore consists, at least to a large extent, of persons who would prefer to be self-employed and are therefore less satisfied with their works an employee.

We extend this discussion by proposing and testing new explanation for a part of the difference in job satisfaction in individual panel data found between the self-employed and employees: anticipation and adaptation effects.

\section{Theoretical considerations}

The theory of the adaptation of subjective well-being measures is based on Brickman and Campbell's (1971) hedonic treadmill model. The authors argue that the appearance of a new incentive causes a temporary shift in subjective well-being. After some time, however, individuals return to their individual baseline or set point of happiness. Frederick and Loewenstein (1999) suggest that adaptation is an automatic habituation process where conscious perception of incentives is reduced when incentives appear constantly or repeatedly. Mechanisms of adaptation include changes in individual ideals, attention, and interests. Diener et al. (2006, p. 302) argue that "the happiness system is thus hypothesized to reflect changes in circumstances rather than the overall desirability of the circumstances themselves." The main conclusion of this model is that life events cannot affect measures of subjective well-being permanently. Further research on adaptation theory has led to changes of Brickman and Campbell's (1971) original model. A review of relevant literature can be found in Diener et al. (2006).

So far, studies which find higher satisfaction levels for the self-employed do not refer to adaptation theory. Hence these analyses implicitly assume that changes in satisfaction levels are of permanent nature. Recent empirical research on adaptation processes finds evidence for adaptation to several life events. For instance Oswald and Powdthavee (2008) find that individuals who become disabled partly adapt in life satisfaction to their disability. Clark et al. (2008) show that there are different anticipation and adaptation effects of life satisfaction to different life events (divorce, birth of child, 
etc.). Lucas's (2005) analysis of adaptation to divorce is another example. Based on their analysis of major life event effects (marriage, divorce, birth of child, widowhood, but not unemployment) in a recent study, Clark and Georgellis (2012) find support using German and British panel data for the hypothesis that adaption may be a general phenomenon.

Another effect, known as the Hawthorne or observer effect, might influence job satisfaction after becoming self-employed. The Hawthorne effect refers to tests in the Hawthorne General Electric firms between 1924 and 1932, where results showed that increased productivity was not attributable to changes in the job environment but rather to increased attention to workers by corporate management and the press (Landsberger 1958). Thus, an individual changes behavior in response to the awareness of being observed rather than in response to changed job conditions, and once the observation (experiment) is over, the prior situation reasserts itself.

The Hawthorne effect might be generously translated to our case in the sense that a change in job satisfaction is not attributable to the job employment change itself but rather to the effect of being observed and faced with the supposed knowledge and aspiration (by society, family or her/himself) that self-employment in general is more satisfying than employment. Such a motivational aspect might influence the actual satisfaction measurement after becoming selfemployed, which would then fade out because of a decreasing influence of aspiration.

So far most interest in the adaptation literature has been focused on analyses of how major life events affect measures of global satisfaction or happiness. Besides Powdthavee (2011), who studied anticipation and adaptation effects in the context of unionization, and Hanglberger (2011b), who examined adaptation to flexible working conditions, up to now there has been no literature on adaptation effects considering job satisfaction. ${ }^{2}$

\subsection{Illustrating adaptation and anticipation effects}

The following graph (see Fig. 1) illustrates how neglected adaptation and anticipation affects estimation results refer to linear fixed effects panel models. Unlike OLS regression based on cross-sectional data, fixed effects regression uses intra-individual variance of independent and dependent variables for estimation. That is, changes in an individual's dependent variable over time are explained by changes in the same person's independent variables.

In a simple model where job satisfaction is solely determined by being self-employed or being an employee, fixed effects regressions estimate the effect of self-employment on job satisfaction by comparing the satisfaction levels of

\footnotetext{
${ }^{2}$ Yet, the present study is based on Hanglberger 2013.
}

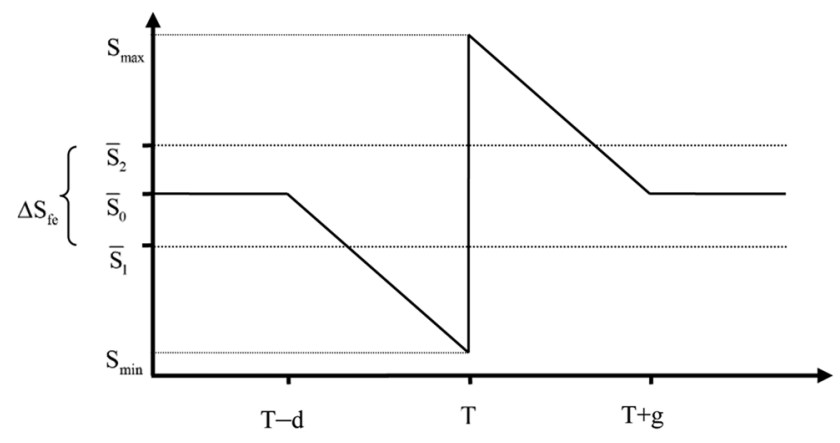

Fig. 1 Fixed effects estimation with negative anticipation and full adaptation. (Source: Own illustration; $\mathrm{x}$-coordinate: time; y-coordinate: job satisfaction)

those individuals who experienced changes in labour force status before and after the change occurred. In other words, the effect of self-employment is estimated as the difference between the average satisfaction as self-employed and the average satisfaction as an employee for those who experience both states.

Assuming that neither adaptation nor anticipation occurs, fixed effects regressions correctly estimate this permanent change in job satisfaction. If following a change to self-employment individuals experience only a temporary upward shift of job satisfaction, fixed effects estimation compares the average satisfaction as employee $\bar{S}_{0}$ with the average satisfaction as self-employed $\bar{S}_{2}$ (see Fig. 1). $\bar{S}_{2}$ is a mixture of positive short-term effects and long-term baseline happiness $\bar{S}_{0}$. Thus the estimation will yield a positive value for $\Delta S_{f e}$ even if self-employment does not cause long-term changes in satisfaction.

A similar effect occurs when the model is extended by anticipation. In Fig. 1 a case of "negative" anticipation is illustrated: Prior to the change to self-employment at time $\mathrm{T}$ satisfaction declines down to $\mathrm{S}_{\min }$. After becoming selfemployed, satisfaction increases up to $S_{\text {max }}$ before individuals adapt to self-employment and satisfaction returns to the base level. In our model the effect of self-employment is estimated as the difference between $\bar{S}_{2}$ and $\bar{S}_{1}$. Thus anticipation can increase the overestimation of $\Delta S_{f e}$ caused by adaption.

Furthermore it can be stated that the influence of anticipation and adaptation on results is larger with short observation periods before and after the change in labour force status. If the aim is to estimate long-term effects, the existence of unaccounted adaptation has as a result the overestimation of long-term effects. Since the existing literature shows that these effects appear for many life events, we believe that studies of causal effects of certain events or incentives on subjective well-being should test for adaptation and anticipation effects whenever possible.

The effect of anticipation on estimation results depends on the sign of anticipation effects. In principle both cases- 
"positive" and "negative" anticipation-might be possible. In our context positive anticipation could also originate from the knowledge of soon becoming self-employed. Unpleasant things might be easier to bear if one knows that they will not last long.

Negative anticipation could be caused by a breakdown of psychological mechanisms which usually leads to a positive self-perception. Knowing that one is soon becoming self-employed, individuals do not deceive themselves about their actual work life anymore and come to a less positive evaluation of working conditions.

A motivational explanation for negative anticipation could be that individuals become self-employed because their satisfaction with work as an employee was decreasing prior to self-employment. This could be the case when working conditions or the perception of working conditions deteriorates. This effect is similar to a phenomenon known in labour economics as Ashenfelter's Dip. In his study on the effects of training programs on earnings, Ashenfelter (1978, p. 55) observed that "all of the trainee groups suffered unpredicted earnings declines in the year prior to training. ... This suggests that simple before and after comparisons of trainees earnings may be seriously misleading evidence on the effect of training on earnings ...". Neglecting this decline in earnings therefore leads to an overestimation of the job training effect.

Ashenfelter did not explicitly explain the reasons behind that dip and in our case there might also be many undetected reasons why we observe a similar picture. However, it might be the case that, in addition to the reasons mentioned above, in the expectation of approaching independent and selfdetermined employment the current job situation and its characteristics appear more disadvantageous than in previous periods, which then results in a drop in job satisfaction.

\section{Data}

In our analyses we used data from the German SocioEconomic Panel Study (SOEP), a nationally representative household panel which has been surveyed since 1984 in West Germany and 1990 in East Germany. The last wave which could be included was Wave 26 (surveyed in 2009). In 2009 10,394 households including 18,587 individuals were interviewed. Besides the items of main interest, employment status and job satisfaction, the SOEP includes information on a wide range of personal, household, and job characteristics (including wages, working hours, and working hour preferences), job history, occupation and industry, and other firm-related characteristics. Table 2 gives an overview of variables and definitions used in our analyses. Further information about sampling, survey methods and development of the SOEP can be found in Wagner et al.
(2007) and Siegel et al. (2010). ${ }^{3}$ For our analysis we used Stata 11.1 and the SOEP long data file.

Job satisfaction in the SOEP is surveyed every year using the question: "How satisfied are you today with the following areas of your life? How satisfied are you with your job?" Individuals rate their job on an 11-point scale ranging from 0 "totally dissatisfied" to 10 "totally satisfied".

To analyse effects caused by changes in employment status between employee status and self-employment, we restricted the sample to individuals who are either selfemployed or employees at date of interview and between 16 and 64 years of age. As self-employed individuals, we defined free-lance liberal professions and other self-employed persons. Family workers and farmers were excluded from the category of the self-employed. Civil servants, blue-collar and white-collar workers were classified as employees. Sixteen individuals who stated they were self-employed as well as employees were classified as self-employed. Observations from 1996 were not included in estimations, since for 1996 there is no information about working hour preference available, which was used as a control variable.

The definition of lag and lead variables (see Chap. 5) meant that observations from Wave 1 to 4 and 23 to 26 could not be included in our analysis, since for these observations no full set of leading and lagged information was available. Furthermore, we could only include individuals who reported being either self-employed or an employee in 9 consecutive years. Individuals with low employability might thus be underrepresented in our estimation sample because they have higher probabilities of becoming unemployed and thereby dropped out of our sample. ${ }^{4}$

A note concerning the interpretation of "anticipation" in our analysis: Narrowly defined, anticipation refers to expecting a new situation, here to being self-employed. However, with our data at hand we were not able to distinguish whether higher or lower job satisfaction before that event was caused by anticipation in this narrow sense or also due to other aspects. Thus we had to be cautious in interpreting the near situation before self-employment as anticipation only in its narrow sense. So, in the following we use the term anticipation (as Clark et al. 2008, p. 230 did) in a broader sense which also captures other influences, including the above-mentioned motivational aspects for dynamics in job satisfaction prior to becoming self-employed.

\footnotetext{
${ }^{3}$ Further information including questionnaires and frequency tables for all items are accessible at: http://panel.gsoep.de/soepinfo2009/

${ }^{4}$ Additional observations could be used if besides employees becoming self-employed also the unemployed becoming self-employed would be considered. We decided against this because the special interest of our paper is to test whether there are differences in satisfaction levels between the self-employed and employees. This also allows us to better compare our results to results from previous studies.
} 


\section{Empirical strategy}

Empirical literature consistently finds higher job satisfaction for the self-employed. Implicitly most analyses maintain the hypothesis that there is a positive and permanent effect of self-employment on job satisfaction. Our analysis aims to test whether the hypothesis is still supported when we account for the anticipation and adaptation effects of subjective well-being.

Benz and Frey (2008) find that individuals who become self-employed experience higher job satisfaction after this change, while there is no drop in job satisfaction for individuals who change from self-employment to work as an employee. Thus when analysing the effect of self-employment on job satisfaction two cases have to be distinguished: changes into and changes out of self-employment. The following analyses focus on changes into self-employment. Individual observations after a change from self-employment to work as an employee are therefore excluded from the analyses.

As described above, we use job satisfaction measured on an 11-point satisfaction scale as a proxy for individual onthe-job utility. Since we cannot determine exact differences in utility between points on this scale, satisfaction is measured with ordinal scaling. Ordinary least squares regression models assume metric scaling of the dependent variable. Hence the use of a regression model which accounts for the ordinal scaling of satisfaction measures is required. Widespread models meeting this demand are latent variable models such as the ordered-logit or ordered-probit model (Long 1997; McKelvey and Zavoina 1975 and recently Greene and Hensher 2010).

A second topic in the analysis of subjective well-being measures is inter-individual comparability. Standard regression models as well as models accounting for ordinal scaling are based on the assumption that satisfaction scores are comparable between individuals. If individuals systematically differ in the rating of same situations, the results of empirical analyses are unreliable. Such differences in ratings might be caused by socialization, genetic, or environmental influences. Respective empirical support was found by Arvey et al. (1989), Lykken and Tellegen (1996), and De Neve et al. (2010).

Further problems arise when components which are not observable or available in data, and therefore not incorporated in a regression model (e.g. genetic factors), affect both job satisfaction and independent variables such as employment status (omitted variable bias). In our context it can be argued that optimistic and risk-taking individuals have higher probabilities to become self-employed and tend to rate their work in a positive way. In this case the estimation of the effect of self-employment on satisfaction is upwardbiased. This bias can also be seen as a causality problem, i.e. does self-employment increase job satisfaction or do happy people become the self-employed?

A solution to dealing with the problem of inter-individual comparability and with unobserved effects such as genetic factors is to use fixed effects regression models. In addition, when there is a program evaluation approach (Heckman et al. 1999) and when becoming self-employed is interpreted as the treatment effect, the fixed effects regression approach solves the selection/omitted variable bias problem by including time invariant unobserved individual heterogeneity. ${ }^{5}$

Our final estimation sample includes 6488 individuals and 37,158 person-year observations. All estimations (independent of the vector of control variables) are based on the same sample to ensure that differences in estimates of different models are not due to differing samples. Descriptive results are based on all person-year observations which fulfil the age and labour force status (employee or self-employed) restriction (see (Table 3).

\subsection{Model I without anticipation and adaptation effects}

Our fixed effects regression model is specified as:

$$
S_{i t}=f_{i t} \gamma+\mathbf{x}_{i t}^{\prime} \beta+a_{i}+\varepsilon_{i t},
$$

where $S_{i t}$ is job satisfaction of individual i at time t. $f_{i t}$ is a dummy variable indicating whether an individual at time $t$ is self-employed $\left(f_{i t}=1\right)$ or an employee $\left(f_{i t}=0\right)$. $\gamma$ is the coefficient measuring the average effect of being self-employed on job satisfaction. $\mathbf{x}_{\mathrm{it}}$ is a vector of control variables and $\beta$ a vector with the respective coefficients. The full set of controls (job, personal household, regional and period variables) is listed in Table 2. $\varepsilon_{i t}$ is the error term and $a_{i}$ represents all unobserved individual characteristics which do not vary over the observation periods. If this unobserved individual heterogeneity is constant over time, it is cancelled out when estimating the model specified in (I) as fixed effects regression. Therefore unobserved individual heterogeneity which is not time varying, such as genetic disposition, does not cause an omitted variable bias in fixed effects models.

Since fixed effects regression uses intra-individual variation over time in independent variables to explain intra-individual variation of the dependent variable, we do not have to base our analysis on the assumption of inter-individual comparability of satisfaction measures. The effect of selfemployment on satisfaction is estimated by the ratings of different situations by the same individual. Hence we only

\footnotetext{
${ }^{5}$ Binder and Coad (2012) follow such a program evaluation approach. However it is based on a matching procedure. They found different effects on life satisfaction when becoming self-employed after being unemployed compared to being employed.
} 
need to make the assumption that the ratings of an individual are consistent over the observation periods.

Using intra-individual variation also implies that our results about how self-employment affects job satisfaction are based on those individuals who moved between both types of employment. A generalisation of our results to all individuals is only allowable if we assume that this group is representative for the whole population (no self-selection processes into selfemployment); an assumption which is rather unlikely.

A plausible solution to handle the ordinal scaling problem in a fixed effects context would be the estimation of an ordered-probit fixed effects model. However Greene (2002) shows that estimates of this model are biased. Recent research using panel data thus employs either linear fixed effects models (assuming metric scaling) or use a POLS (probit-adapted ordinary least squares) approach as suggested by van Praag and Ferrer-I-Carbonell (2008). The van Praag and Ferrer-I-Carbonell model is based on an additional assumption, namely that subjective well-being is normally distributed. Since the POLS model relaxes one assumption by making another one, and Ferrer-I-Carbonell and Frijters (2004) find that differences in estimators are rather small when assuming the cardinality or ordinality of satisfaction measures, we decided to estimate linear fixed effects models only.

In Equation (I) we specified a model with a coefficient which captures the ceteris paribus difference in job satisfaction between years in self-employment and years as an employee. The difference of this estimate is based only on those individuals who moved between employee status and self-employment during the observation periods. As discussed above, the literature shows that many events or incentives do not cause constant changes of satisfaction measures, but rather that people adapt to changes, and satisfaction sometimes anticipates events.

\subsection{Model II with anticipation and adaptation to self- employment}

To account for anticipation and adaptation effects, we follow the specification suggested by Frijters et al. (2011) and Clark et al. (2008) and specify Model (II):

$$
\begin{aligned}
S_{i t}= & f_{i t, T-4} \gamma_{T-4}+f_{i t, T-3} \gamma_{T-3} \\
& +f_{i t, T-2} \gamma_{T-2}+f_{i t, T-1} \gamma_{T-1}+f_{i t, T} \gamma_{T} \\
& +f_{i t, T+1} \gamma_{T+1}+f_{i t, T+2} \gamma_{T+2}+f_{i t, T+3} \gamma_{T+3} \\
& +f_{i t, T+4+} \gamma_{T+4+}+\mathbf{x}_{i t}^{\prime} \beta+a_{i}+\varepsilon_{i t},
\end{aligned}
$$

where $f_{i t, T-4}$ to $f_{i t, T+4+}$ are dummy variables indicating whether an individual is self-employed, how long he is self-employed or if he will become self-employed within the next years. $\mathrm{f}_{\mathrm{it}, \mathrm{T}}$ is 1 only if individual $i$ did work as an employee the year before $t$ and is self-employed at the time of interview in year $t$. Otherwise $f_{i t, T}$ is $0 .^{6}$

In order to describe adaptation, the model is extended by four dummies $\mathrm{f}_{\mathrm{it}, \mathrm{T}+1}, \mathrm{f}_{\mathrm{it}, \mathrm{T}+2}, \mathrm{f}_{\mathrm{it}, \mathrm{T}+3}$, and $\mathrm{f}_{\mathrm{it}, \mathrm{T}+4}$ indicating that an individual is self-employed since and throughout $1-2$, $2-3,3-4$, or more than 4 years. Anticipation of changes in labour force status are captured by the dummies $\mathrm{f}_{\mathrm{it}, \mathrm{T}-1}, \mathrm{f}_{\mathrm{it}, \mathrm{T}-2}$, $\mathrm{f}_{\mathrm{it}, \mathrm{T}-3}$ and $\mathrm{f}_{\mathrm{it}, \mathrm{T}-4}$. These dummies analogously indicate that individual $i$ will become self-employed within the next year, $1-2,2-3$, or $3-4$ years.

The dummies $\mathrm{f}_{\mathrm{it}, \mathrm{T}-4}$ to $\mathrm{f}_{\mathrm{it}, \mathrm{T}+4_{+}}$in (II) are defined in such a way that only one of the dummies can be 1 and all other dummies must be 0 . If an individual is neither self-employed nor becoming self-employed within the next 4 years, all dummy variables are 0 . Hence the coefficients can be interpreted with reference to those years when an individual is an employee and is not becoming self-employed in the coming 4 years. ${ }^{7}$ For example ${ }_{\gamma \mathrm{T}}$ is the ceteris paribus average difference in satisfaction of individuals who are in their first year of self-employment, compared to the time when they were not self-employed and not becoming self-employed within the next 4 years.

\subsection{Model III with anticipation and adaptation for any job change}

Theoretically, anticipation, adaptation, and the long-term effects of becoming self-employed found by regression estimates could be due to a general effect caused by any job change regardless of a change between being an employee and being self-employed. ${ }^{8}$ We will test whether this is the case by extending Equation (I) by the dummies $c_{i t, T-4}$ to $c_{i t T+4}$. Those dummies capture anticipation and adaptation effects on a change of jobs, which might also be a change between two employee jobs. The dummies are defined anal-

${ }^{6}$ The data only allows a one-year perspective, i.e. the individuals have to be characterized as self-employed or an employee within a certain year regardless whether it is at the beginning or the end of the year. Thus, $\mathrm{t}-1$ could characterize 1 month or 11 months, say, before changing to self-employment. The estimated effect therefore is some average over the year.

${ }^{7}$ This includes years when an individual changed from being selfemployed to working as an employee.

${ }^{8} \mathrm{Job}$ changes and job satisfaction with respect to quit behavior is analyzed by Levy-Garboua et al. 2007. The propensity to quit a job for Levy-Garboua is based on a microeconomic model where the expected present value becomes lower in their present job than in an alternative job or non-employment. Though the interesting link between quit and satisfaction might be transformed in our case into a pure job change mobility model (between two employee jobs or even between employment and self-employment), the Levy-Garboua et al. approach is still a mobility model where transformed satisfaction is the explanatory variable to explain job change propensity. In our model, however, job satisfaction is the variable to be explained so this approach does not really fit our concerns. 
ogously to $f_{i t, T-4}$ to $f_{i t, T+4+}$ as introduced in Equation (II) with respect to self-employment. Only the definition of $c_{i t, T+4}$ (general job change 4-5 years ago) differs from $f_{i t, T+4+}$ (selfemployed since more than 4 years). Thus in specification (III) we control for anticipation and adaptation to any job change and capture self-employment with a single dummy variable.

$$
\begin{aligned}
S_{i t}= & f_{i t} \gamma+c_{i t, T-4} \delta_{T-4}+c_{i t, T-3} \delta_{T-3} \\
& +c_{i t, T-2} \delta_{T-2}+c_{i t, T-1} \delta_{T-1}+c_{i t, T} \delta_{T} \\
& +c_{i t, T+1} \delta_{T+1}+c_{i t, T+2} \delta_{T+2}+c_{i t, T+3} \delta_{T+3} \\
& +c_{i t, T+4} \delta_{T+4}+\mathbf{x}_{i t} \beta+a_{i}+\varepsilon_{i t}
\end{aligned}
$$

5.4 Model IV with anticipation and adaptation for any job change and self-employment

In a last specification (IV) we test whether there are separate anticipation and adaptation effects on self-employment compared to job changes in general. Thus we include $c_{i t, T-4}$ to $c_{i t, T+4}$ to capture adaptation and anticipation to any job changes and $f_{i t, T-4}$ to $f_{i t, T+4+}$ to account for separate anticipation and adaptation effects of self-employment.

$$
\begin{aligned}
S_{i t}= & f_{i t, T-4} \gamma_{T-4}+f_{i t, T-3} \gamma_{T-3} \\
& +f_{i t, T-2} \gamma_{T-2}+f_{i t, T-1} \gamma_{T-1}+f_{i t, T} \gamma_{T} \\
& +f_{i t, T+1} \gamma_{T+1}+f_{i t, T+2} \gamma_{T+2} \\
& +f_{i t, T+3} \gamma_{T+3}+f_{i t, T+4+} \gamma_{T+4+} \\
& +c_{i t, T-4} \delta_{T-4}+c_{i t, T-3} \delta_{T-3} \\
& +c_{i t, T-2} \delta_{T-2}+c_{i t, T-1} \delta_{T-1}+c_{i t, T} \delta_{T} \\
& +c_{i t, T+1} \delta_{T+1}+c_{i t, T+2} \delta_{T+2}+c_{i t, T+3} \delta_{T+3} \\
& +c_{i t, T+4} \delta_{T+4}+\mathbf{x}_{i t} \beta+a_{i}+\varepsilon_{i t}
\end{aligned}
$$

Fig. 2 Average job satisfaction of the self-employed and employees in Germany 1984-2009. (Source: Own calculations based on SOEP 1984-2009; weighted data, age 16-64)
Table 1 Overview of estimated regression models. (Source: Own compilation, for a detailed list and description of control variables see Table 2)

\begin{tabular}{llll}
\hline Model & Self-employment & Job change & Controls \\
\hline I & Dummy & - & Yes \\
II & Anticipation and adaptation & - & Yes \\
III & Dummy & $\begin{array}{l}\text { Anticipation and } \\
\text { adaptation }\end{array}$ & Yes \\
IV & Anticipation and adaptation & $\begin{array}{l}\text { Anticipation and } \\
\text { adaptation }\end{array}$ & Yes \\
& & & \\
\hline
\end{tabular}

All estimations include the same vector of controls $\mathbf{x}$ (see Table 2). Table 1 summarizes all regression models, which we will present in the following chapter.

\section{Results}

The job satisfaction of the self-employed in Germany is on average higher than for employees (7.20 compared to 7.05 on an 11-point scale). As can be seen in Fig. 2 average satisfaction of both subgroups follows a similar trend over time, but there are considerable differences in the gap between job satisfaction for employees and the self-employed. For 3 out of 26 years the average is slightly higher for employees.

The following analysis deals with possible anticipation and adaptation effects of self-employment or job changes in general. A first impression can be received from Fig. 3. The figure shows the average job satisfaction of individuals who become self-employed within the next 4 years $(T-4, \ldots$, $\mathrm{T}-1)$, became self-employed within the last 4 years $(\mathrm{T}, \ldots$, $\mathrm{T}+3$ ) or have been self-employed for more than 4 years $(\mathrm{T}+4+)$. It can be seen that job satisfaction decreases by 0.2 points in the year prior to self-employment. With the change

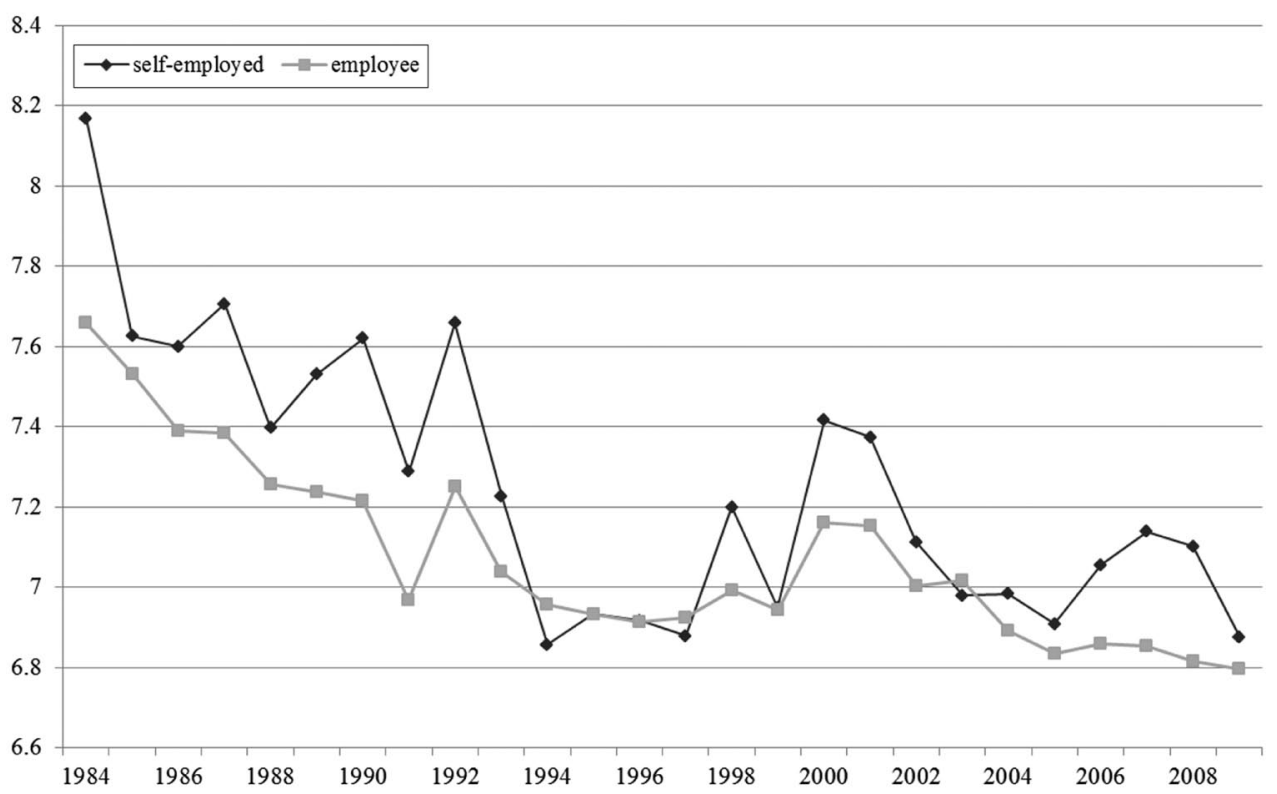


Fig. 3 Average job satisfaction before and after a move from an employee job to self-employment. (Notes: T-4: $3-4$ years prior to self-employment, etc., $\mathrm{T}$ : first year of self-employment, $\mathrm{T}+1$ : second year in self-employment, etc., $\mathrm{T}+4+$ : self-employed since at least 4 years. Source: Own calculations based on SOEP 1984-2009; weighted; age 16-64)
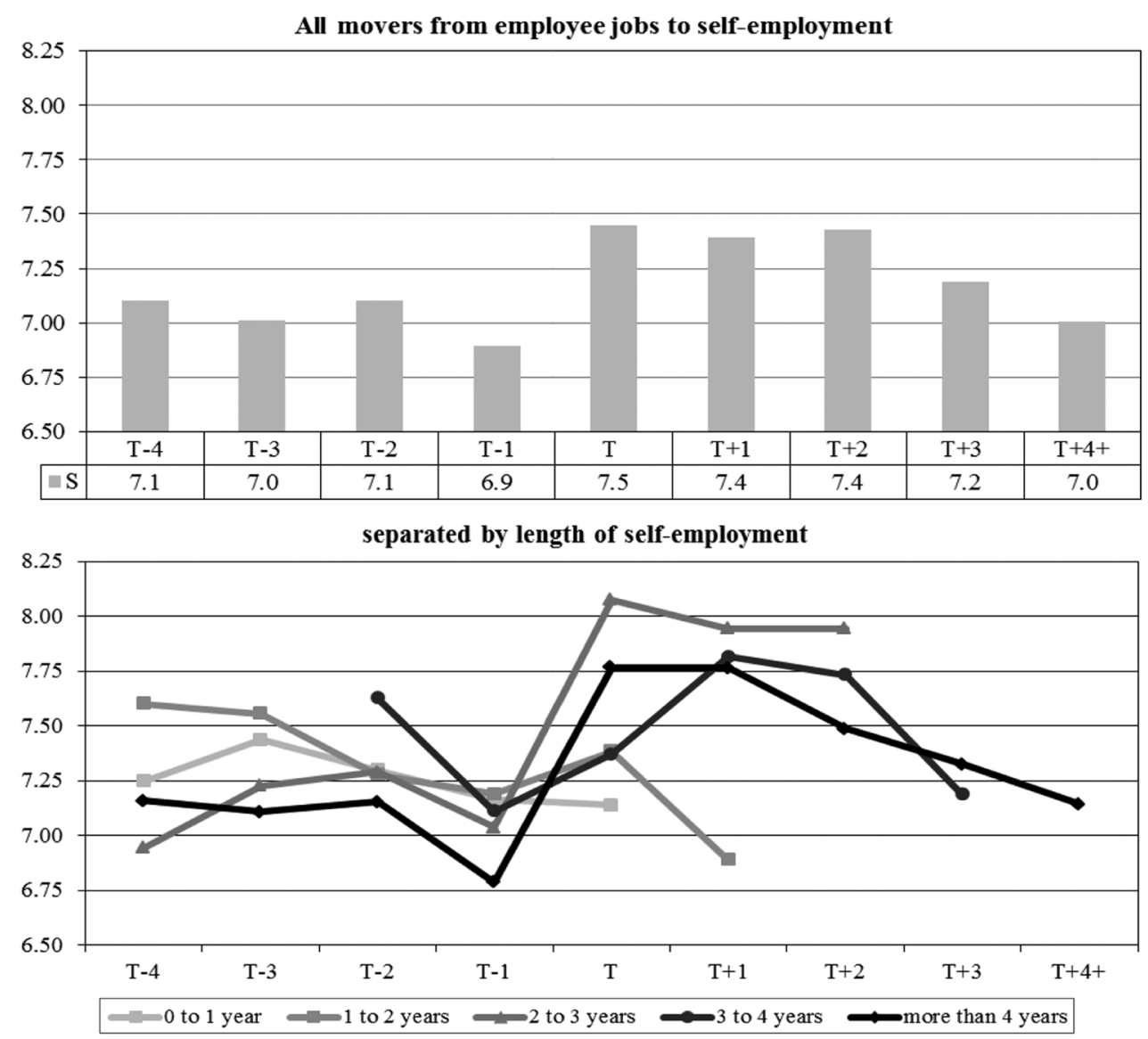

from work as an employee to self-employment, job satisfaction raises by 0.6 points. This level of job satisfaction is held for 3 years. After 3 years, satisfaction drops back to the exante level of satisfaction. The second part of Fig. 3 shows that individuals who change back to being an employee within 2 years experienced only a small or no increase in job satisfaction. The development of job satisfaction for those who stay self-employed for 3, 4 or more than 4 years is quite similar and indicates that there is a negative anticipation and adaptation to self-employment.

\subsection{Model I without anticipation and adaptation effects}

As a first step in our analysis we estimated Model I to reproduce the result found by several empirical studies that job satisfaction is higher for the self-employed than for employees. This result can be interpreted as an average higher satisfaction level for the same individuals when self-employed than when working as an employee. After controlling for income, working hours and other variables, we find that the effect of self-employment amounts to approximately 0.59 points on an 11-point satisfaction scale. A result which is in line with previous findings.
6.2 Model II with anticipation and adaptation to selfemployment

To test whether the effect of self-employment found in Model I might be caused by anticipation and adaptation effects as discussed in Chap. 3, we estimated Model II, which includes dummy variables to capture adaptation and anticipation effects on self-employment for up to 4 years. Estimation results are shown graphically in Fig. 4 and detailed in Table 5. The coefficients of Model II can be interpreted as the average difference in job satisfaction after being self-employed for a certain number of years (adaptation) or becoming self-employed in a certain number of years (anticipation) compared to working as an employee with no upcoming self-employment within the next 4 years.

There is no significant anticipation effect estimated, but during the first year in self-employment individuals experience a remarkable upward shift in job satisfaction, especially compared to the preceding year. The effect amounts to $1.06\left(\gamma_{T}-\gamma_{T-1}\right)$ points on average. Individuals hold this satisfaction level for approximately 3 years before satisfaction drops back to the baseline.

As illustrated in Fig. 1 unaccounted adaptation to selfemployment will lead to an overestimation of long-term 


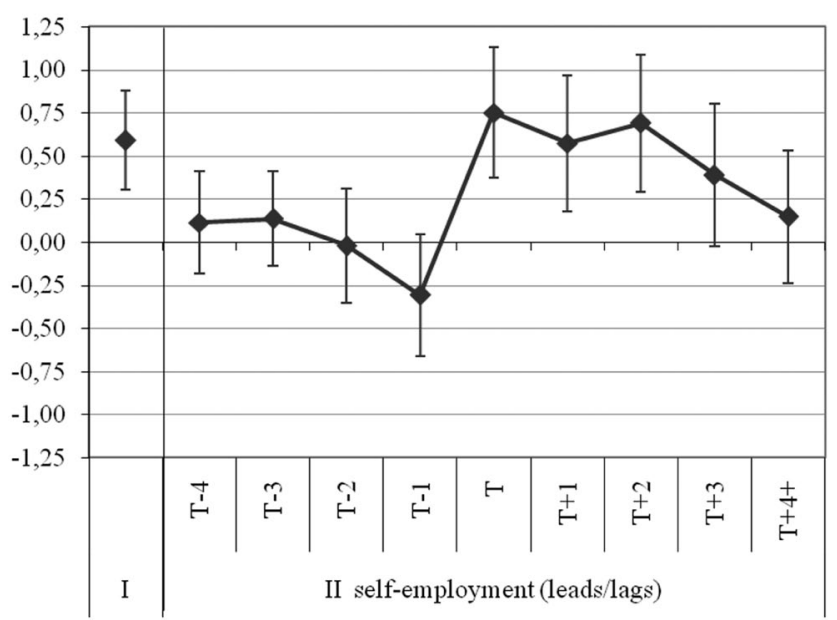

Fig. 4 The effect of self-employment on job satisfaction in fixed effects regression models with and without accounting for anticipation and adaptation. (Note: $90 \%$ confidence intervals (robust standard errors); for detailed regression results see Table 5; for descriptive statistics on estimation sample see Table 3. Source: Own illustration based on fixed effects regression Models I and II with control variables based on SOEP data 1984-2009)

effects. This theoretically derived result fits our empirical findings. The effect of self-employment is found to be positive in Model I, while in Model II with adaptation and anticipation we find no significant long-term effect. So far our results suggest that self-employment does not raise job satisfaction in the long run, but individuals who become self-employed experience significantly higher job satisfaction for approximately 3 years.

\subsection{Model III with anticipation and adaptation for any job change}

In Model II we analysed anticipation and adaptation of movers from employee work to self-employment. Of course the same anticipation and adaptation effects might occur when individuals move between two employee jobs. To test whether the estimated effect is a general effect accompanying any change of jobs rather than a specific effect of self-employment, we estimate two more models. Model III accounts for anticipation and adaptation to a change of jobs regardless of whether the change involves a change between two employee jobs and becoming self-employed after being an employee. In this setting self-employment is included in the model as a single dummy variable. Model IV accounts separately for adaptation and anticipation to job changes in general and to changes from being an employee to being self-employed.

Accounting for anticipation and adaptation of job changes reduces the effect of self-employment on job satisfaction substantially. We found a significant difference of 0.59 points in Model I, Model III estimates an approxi-

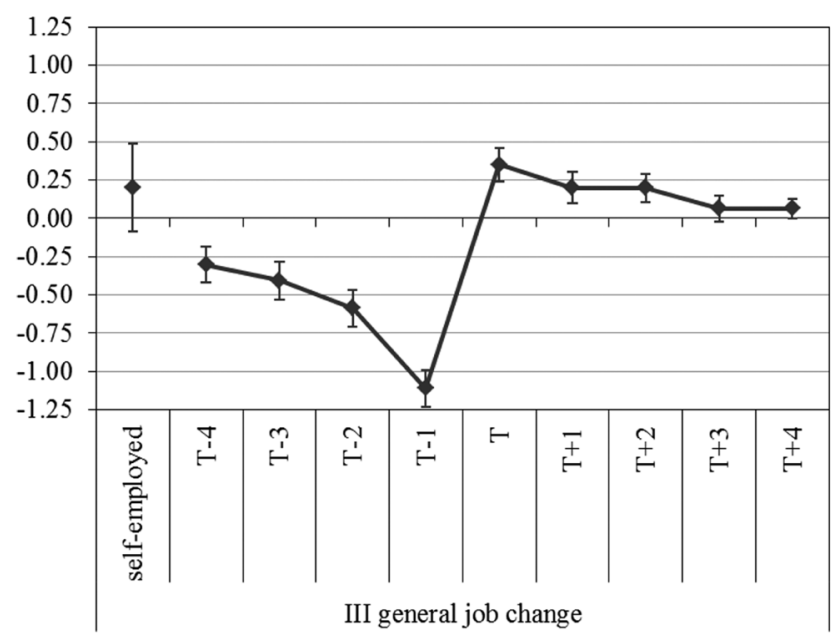

Fig. 5 The effect of general job change on job satisfaction in fixed effects regression models when accounting for anticipation and adaptation. (Note: $90 \%$ confidence intervals (robust standard errors); for detailed regression results see Table 5; for descriptive statistics on estimation sample see Table 3. Source: Own illustration based on fixed effects regression Model III with control variables based on SOEP data 1984-2009)

mately two-thirds lower and not significant effect of 0.20 points. Thus the results support the view that the largest part of higher job satisfaction of the self-employed found by studies based on fixed effects regressions can be explained without accounting for anticipation and adaptation to job changes (see Fig. 5).

Job changes in general seem to be accompanied by very pronounced negative anticipation effects. The upward shift in job satisfaction in the first year is even more pronounced than for self-employment in estimation of Model II. Similar to adaptation to self-employment there seems to be adaptation to job changes in general as well.

\subsection{Model IV with anticipation and adaptation for any job change and for self-employment}

In Model III (Fig. 5) we do not allow for different anticipation and adaptation patterns for changes from employee jobs to self-employment and changes between two employee jobs. Model IV extends Model III by estimating specific anticipation and adaptation effects on self-employment. Since a change to self-employment is also a job change in general, coefficients of anticipation and adaptation to selfemployment in Model IV should be interpreted as a deviation from the anticipation and adaptation pattern for general job changes.

The extension of our model has a negligible effect on anticipation and adaption effects on general job changes (Fig. 6). Considering a change involving becoming selfemployed, we find significant positive anticipation and a significant positive effect of self-employment for 3-4 years. 
Fig. 6 The effect of general job change and self-employment on job satisfaction in fixed effects regression models when accounting for anticipation and adaptation. (Note: $90 \%$ confidence intervals (robust standard errors); for detailed regression results see Table 5; for descriptive statistics on estimation sample see Table 3 . Source: Own illustration based on fixed effects regression Model IV with control variables based on SOEP data 1984-2009)

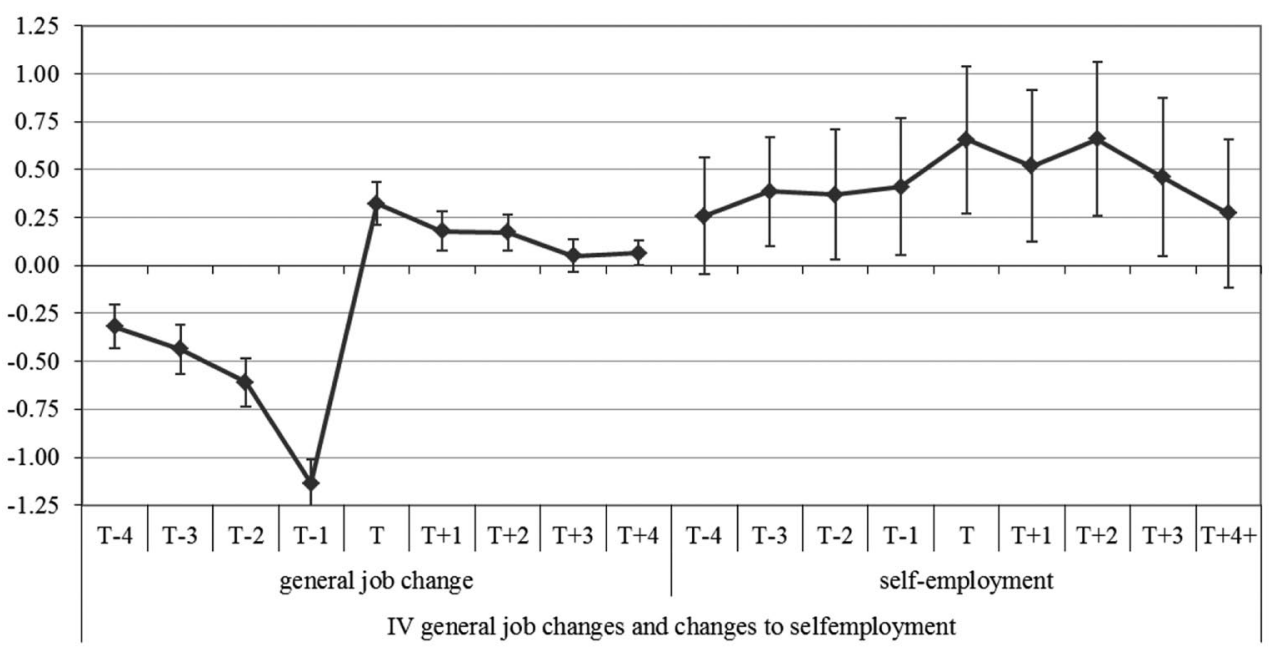

Thus negative anticipation for individuals who become self-employed is less pronounced and the gain in the first 3 years of self-employment is substantially higher than for job changes in general. Nevertheless there is no significant long-term effect of self-employment on job satisfaction.

To sum up, our results contradict the widespread finding that self-employed individuals experience substantially higher satisfaction levels than employees. As our results show, once anticipation and adaptation are considered, no statistically significant long-term differences in job satisfaction between the self-employed and employees are visible.

\subsubsection{Main findings}

- The estimates of long-term effects on measures of subjective well-being might be misleading when anticipation and adaptation effects are neglected.

- Individuals who become self-employed noticeably improve their level of job satisfaction, especially when compared to the year before self-employment.

- Positive effects of self-employment on job satisfaction are only found for the first 3 years of self-employment; long-term effects are not significant as individuals adapt to self-employment.

\section{Discussion and conclusion}

The aim of this study is to test whether the higher levels of job satisfaction of the self-employed compared to employees found by many previous studies might be due to neglecting anticipation and adaptation effects in measures of subjective well-being.

We theoretically derive how estimates of the effect of self-employment in fixed effects regression models might be misleading in the presence of anticipation and/or adaptation effects. Our estimates show that individuals who become self-employed noticeably improve their level of job satisfaction when compared to the year before self-employment. However the positive effect of self-employment lasts for only 3 years.

Furthermore, we estimate fixed effects regression models which account for anticipation and adaptation of job satisfaction to job changes independent of a change in self-employment. Due to our data base, anticipation encompasses not only a lookahead to self-employment but also other influences prior to becoming self-employed. Our results show that negative anticipation effects are a general and pronounced effect preceding any change of jobs. Individuals who become self-employed experience less distinctive negative anticipation. A positive effect of selfemployment on job satisfaction lasting 3 years is also found in this model. In the long run we find that the self-employed are not better off than employees; put more precisely, we cannot reject the hypothesis that job satisfaction is ceteris paribus the same for the self-employed and employees.

So our results contradict the findings presented by e.g. Blanchflower and Oswald (1998) and Clark and Senik (2006). The concept of procedural utility as an explanation for differences in satisfaction levels as proposed by Benz and Frey $(2004,2008)$ is also not supported by our results. If there is a utility gain from the higher procedural utility of self-employment, the effect is not lasting. Our results suggest that the experience of procedural utility is not constant or, in other words, procedural utility is subject to adaptation effects. Furthermore, our results do not support the hypothesis of capital constraints causing differences in job satisfaction (Blanchflower and Oswald 1998), since there is no long-term effect of self-employment on job satisfaction.

So, the general question remains: why do individuals become self-employed when the mentioned reasons including even no long-termed job satisfaction do not really count? May be people have unrealistic and/or exaggerated 
expectations, may be people have no job alternatives as an employee; may be there is a mix of many reasons.

The group of the self-employed analysed is a very heterogeneous group. The group consists of free-lance professionals and other self-employed persons. One can imagine that the working life of a free-lance professional is quite different than the working life of a business owner; and, there is heterogeneity between various business owners. This difference might explain to a certain extent the large variance of the estimates of self-employment on job satisfaction when accounting for anticipation and adaptation effects.

Questions remain for future research including the look at differences between subgroups of the self-employed such as free-lancers and business owners. Furthermore, it would be interesting to see how life satisfaction or different subdomains of job satisfaction such as satisfaction with pay or with hours worked respond to changes in employment status.

\section{Executive summary}

The economic and societal importance of the self-employed is unquestioned and is studied in a number of different fields (Parker 2009). Besides other aspects, job satisfaction of the self-employed has been of increasing interest within the last decade. Empirical research on job satisfaction in numerous studies has found that self-employed persons show substantially higher levels of job satisfaction than employees. This result has been consistently confirmed across Europe (e.g. Blanchflower and Oswald 1998; Blanchflower 2000; Benz and Frey 2004, 2008; Clark and Senik 2006) and for the USA and Canada (Kawaguchi 2008; Hundley 2001; Benz and Frey 2004). Among these papers are analyses based on cross sections as well as studies exploiting individual panel data to follow individuals over time.

With our analysis we contribute to the literature by proposing and testing a new explanation for a part of the difference in job satisfaction found in individual panel data between the self-employed and employees: anticipation and adaptation effects.

Adaption and anticipation effects can distort results when estimating regression models. For example, anticipation can distort effect results when individuals tend to be very dissatisfied with their employee work in the years before becoming self-employed. This leads to a comparable higher satisfaction level for the same individuals when self-employed, even when there is no lasting effect of self-employment on job satisfaction. In case of adaptation effects, individuals experience short-term benefits in subjective well-being after becoming self-employed. After some years people become used to being self-employed and satisfaction tends back to the baseline level.
Thus the main questions we address in this paper are:

- Are there anticipation effects which affect the estimation of the effect of self-employment on job satisfaction?

- Is there a long-term positive effect of self-employment on job satisfaction, or does individual satisfaction adapt to self-employment and return to an ex-ante satisfaction level?

We theoretically derive how estimates of the effect of selfemployment in fixed effects regression models might be misleading in the presence of anticipation and/or adaptation effects. Our estimates show that individuals who become self-employed noticeably improve their level of job satisfaction when compared to the year before self-employment. However the positive effect of self-employment lasts for only 3 years.

Furthermore, we estimate fixed effects regression models which account for anticipation and adaptation of job satisfaction to job changes independent of a change in self-employment. Due to our data base, anticipation encompasses not only a lookahead to self-employment but also other influences prior to becoming self-employed. Our results show that negative anticipation effects are a general and pronounced effect preceding any change of jobs. Individuals who become self-employed experience less distinctive negative anticipation. A positive effect of selfemployment on job satisfaction lasting 3 years is also found in this model. In the long run we find that the self-employed are not better off than employees; put more precisely, we cannot reject the hypothesis that job satisfaction is ceteris paribus the same for the self-employed and employees.

So our results contradict the findings presented by e.g. Blanchflower and Oswald (1998) and Clark and Senik (2006). The concept of procedural utility as an explanation for differences in satisfaction levels as proposed by Benz and Frey $(2004,2008)$ is also not supported by our results. If there is a utility gain from the higher procedural utility of self-employment, the effect is not lasting. Our results suggest that the experience of procedural utility is not constant or, in other words, procedural utility is subject to adaptation effects. Furthermore, our results do not support the hypothesis of capital constraints causing differences in job satisfaction (Blanchflower and Oswald 1998), since there is no long-term effect of self-employment on job satisfaction.

\section{Kurzfassung}

Aufgrund ihrer ökonomischen und gesellschaftlichen Bedeutung wird die Tätigkeit von Selbständigen aus vielen unterschiedlichen Perspektiven wissenschaftlich untersucht (Parker 2009). Zunehmende Aufmerksamkeit findet dabei die Arbeitszufriedenheit von Selbständigen. So haben zahl- 
reiche empirische Studien Belege für eine höhere Arbeitszufriedenheit von Selbständigen gefunden. $\mathrm{Zu}$ diesem Ergebnis kommen übereinstimmend europäische Studien (z. B. Blanchflower und Oswald 1998; Blanchflower 2000; Benz und Frey 2004, 2008; Clark und Senik 2006) und Studien für die USA und Kanada (Kawaguchi 2008; Hundley 2001; Benz und Frey 2004). Unter diesen Studien finden sich sowohl Querschnittsanalysen, als auch Panelanalysen, die es ermöglichen, die Entwicklung einzelner Individuen im Zeitverlauf zu verfolgen. Mit unserem Beitrag untersuchen wir, ob dieses empirische Ergebnis möglicherweise auf die Vernachlässigung von Antizipations- und Adaptionseffekten zurückgeführt werden kann.

Antizipation und Adaption können die Ergebnisse empirischer Untersuchungen verzerren. Dies geschieht beispielsweise wenn Personen in den Jahren vor ihrer Selbständigkeit besonders unzufrieden mit ihrer abhängigen Beschäftigung sind. Vergleicht man in dieser Konstellation die Zufriedenheit nach dem Übergang in Selbständigkeit mit dem Niveau der Zufriedenheit vor der Selbständigkeit, so ergibt sich eine höhere Zufriedenheit für die Zeit der Selbständigkeit, auch wenn diese keinen dauerhaft positiven Effekt hat. Analog kann es zu einer Überschätzung des positiven Effekts der Selbständigkeit kommen, wenn ein positiver Effekt nur temporär Auftritt. So ist es denkbar, dass sich Personen nach einer gewissen Zeit an die positiv wahrgenommenen Aspekte der Selbständigkeit gewöhnen und die Arbeitszufriedenheit wieder auf das Ausgangsniveau sinkt (Adaption).

Die in diesem Beitrag adressierten Fragen lauten somit:

- Gibt es Antizipationseffekte, die die Schätzung des Effekts von Selbständigkeit auf die Arbeitszufriedenheit beeinflussen?

- Erhöht Selbständigkeit langfristig die Arbeitszufriedenheit oder werden positive Effekte adaptiert?

Zunächst zeigen wir theoretisch, welchen Einfluss Antizipation und Adaption auf die Ergebnisse von fixed-effects Regressionsmodellen haben können. Um den Sachverhalt empirisch zu überprüfen, spezifizieren wir fixed-effects Regressionsmodelle, die auch Antizipation und Adaption der Arbeitszufriedenheit vor einem Wechsel aus abhängiger Beschäftigung in Selbständigkeit berücksichtigen. Grundlage für unsere Analyse ist das Sozio-oekonomische Panel (SOEP) der Jahre 1984-2009. Die Schätzungen zeigen, dass
Personen mit dem Übergang in Selbständigkeit im Durchschnitt eine deutliche Erhöhung der Arbeitszufriedenheit erfahren. Dieser positive Effekt hält circa drei Jahre an und wird in der Folge adaptiert.

Um zu berücksichtigen, dass Antizipation und Adaption nicht nur bei einem Übergang aus abhängiger Beschäftigung in Selbständigkeit auftreten kann, sondern auch, wenn Personen in eine andere abhängige Beschäftigung wechseln, schätzen wir Modelle, die Antizipation und Adaption allgemein bei einem Arbeitsplatzwechsel und speziell beim Übergang in Selbständigkeit getrennt erfassen.

Auf Grundlage der vorliegenden Daten kann nicht zwischen Antizipation im engeren Sinne und anderen Einflüssen, die vor dem Arbeitsplatzwechsel auftreten, unterschieden werden. Der Begriff Antizipation ist hier deshalb in einem weiteren Sinne zu verstehen, der beide Aspekte umfasst.

Unsere Analysen verdeutlichen, dass der Wechsel eines Arbeitsplatzes allgemein mit ausgeprägten negativen Antizipationseffekten einhergeht. Bei Personen, die aus abhängiger Beschäftigung in Selbständigkeit wechseln, fällt diese negative Antizipation deutlich geringer aus. Auch in diesem Modell zeigt sich ein positiver Effekt der Selbständigkeit auf die Arbeitszufriedenheit über drei Jahre. Langfristig erzielen Selbständige jedoch keine signifikant höhere Arbeitszufriedenheit. Die Hypothese, ceteris paribus sei die Arbeitszufriedenheit von Selbständigen und abhängig Beschäftigten auf lange Frist gleich, kann in unserem Modell nicht verworfen werden.

Unsere Ergebnisse stehen damit im Widerspruch zu Arbeiten z.B. von Blanchflower und Oswald (1998) und Clark und Senik (2006). Die Adaption der positiven Effekte der Selbständigkeit spricht gegen die von Blanchflower und Oswald (1998) angeführte Hypothese, die unterschiedliche Zufriedenheit sei auf Kapitalbeschränkungen zurückzuführen. Auch das von Benz und Frey $(2004,2008)$ vorgeschlagene Konzept des procedural utility als Erklärung für die unterschiedlichen Zufriedenheitsniveaus abhängig Beschäftigter und Selbständiger wird durch diese Ergebnisse nicht gestützt. Falls Selbständige durch ein höheres Niveau an procedural utility einen Nutzenzugewinn erzielen, so ist dieser Zugewinn nicht dauerhaft sondern unterliegt Adaptionseffekten. 


\section{Appendix}

Table 2 Variables and definitions. (Source: Own compilation)

\begin{tabular}{|c|c|}
\hline Variable & Definition \\
\hline \multicolumn{2}{|c|}{$\overline{\text { Self employment (lags and leads) }}$} \\
\hline Self-employed & Dummy \\
\hline Self-employed T-4 & $\begin{array}{l}\text { Dummy; will become self-employed in } 4-5 \\
\text { years, employee till then }\end{array}$ \\
\hline Self-employed T-3 & $\begin{array}{l}\text { Dummy; will become self-employed in 3-4 } \\
\text { years, employee till then }\end{array}$ \\
\hline Self-employed T-2 & $\begin{array}{l}\text { Dummy; will become self-employed in } 2-3 \\
\text { years, employee till then }\end{array}$ \\
\hline Self-employed T-1 & $\begin{array}{l}\text { Dummy; will become self-employed in 1-2 } \\
\text { years, employee till then }\end{array}$ \\
\hline Self-employed T & $\begin{array}{l}\text { Dummy; became self-employed during the } \\
\text { last year }\end{array}$ \\
\hline Self-employed $\mathrm{T}+1$ & $\begin{array}{l}\text { Dummy; became self-employed 1-2 years } \\
\text { ago, since then self-employed }\end{array}$ \\
\hline Self-employed $\mathrm{T}+2$ & $\begin{array}{l}\text { Dummy; became self-employed } 2-3 \text { years } \\
\text { ago, since then self-employed }\end{array}$ \\
\hline Self-employed $\mathrm{T}+3$ & $\begin{array}{l}\text { Dummy; became self-employed 3-4 years } \\
\text { ago, since then self-employed }\end{array}$ \\
\hline Self-employed $\mathrm{T}+4+$ & $\begin{array}{l}\text { Dummy; became self-employed more than } 4 \\
\text { ago, since then self-employed }\end{array}$ \\
\hline \multicolumn{2}{|c|}{ Job change (lags and leads) } \\
\hline Job change $\mathrm{T}-4$ & $\begin{array}{l}\text { Dummy; will change job in } 4-5 \text { years, in the } \\
\text { same job till then }\end{array}$ \\
\hline Job change $\mathrm{T}-3$ & $\begin{array}{l}\text { Dummy; will change job in } 3-4 \text { years, in the } \\
\text { same job till then }\end{array}$ \\
\hline Job change $T-2$ & $\begin{array}{l}\text { Dummy; will change job in } 2-3 \text { years, in the } \\
\text { same job till then }\end{array}$ \\
\hline Job change $T-1$ & $\begin{array}{l}\text { Dummy; will change job in } 1-2 \text { years, in the } \\
\text { same job till then }\end{array}$ \\
\hline Job change $T$ & Dummy; changed job during the last year \\
\hline Job change $\mathrm{T}+1$ & $\begin{array}{l}\text { Dummy; changed job } 1-2 \text { years ago, since } \\
\text { then in same job }\end{array}$ \\
\hline Job change $\mathrm{T}+2$ & $\begin{array}{l}\text { Dummy; changed job } 2-3 \text { years ago, since } \\
\text { then in same job }\end{array}$ \\
\hline Job change $\mathrm{T}+3$ & $\begin{array}{l}\text { Dummy; changed job } 3-4 \text { years ago, since } \\
\text { then in same job }\end{array}$ \\
\hline Job change $\mathrm{T}+4$ & $\begin{array}{l}\text { Dummy; changed job } 4-5 \text { years ago, since } \\
\text { then in same job }\end{array}$ \\
\hline
\end{tabular}

$J o b$

Job satisfaction

$\ln ($ personal income)

Experience full-time Years of labour market experience as full-

Experience part-time Years of labour market experience as part-

Experience unemployment Activity is job Working hours Working hours ${ }^{2}$ Work less time worker time worker

(Dependent variable) 11-point scale: $0=$ totally unhappy, $10=$ totally happy

$\ln$ (monthly net income (earned), $€$ )

Years of labour market experience as unemployed

Activity is job

Working hours per week

Working hours per week ${ }^{2} / 100$

Would prefer to work X hours less, when taking into account that income would change accordingly(not available for 1996, observations from 1996 are excluded from regression estimations)
Table 2 (Continued)

\begin{tabular}{|c|c|}
\hline Variable & Definition \\
\hline Work more & $\begin{array}{l}\text { Would prefer to work X hours more, when } \\
\text { taking into account that income would } \\
\text { change accordingly (not available for 1996, } \\
\text { observations from } 1996 \text { are excluded from } \\
\text { regression estimations) }\end{array}$ \\
\hline Part-time & $\begin{array}{l}\text { Dummy; part time worker with } 5-29 \mathrm{~h} \text { of } \\
\text { work per week }\end{array}$ \\
\hline Liberal profession & Dummy \\
\hline Occupation & $\begin{array}{l}25 \text { dummies for occupations based on } \\
\text { ISCO } 88 \text { classification: Military; Legislators } \\
\text { and senior officials; Corporate managers; } \\
\text { Managers of small enterprises; Physical, } \\
\text { mathematical, and engineering science } \\
\text { professionals; Life science and health } \\
\text { professionals; Teaching professionals; Other } \\
\text { professionals; Physical and engineering } \\
\text { science associate professionals; Life science } \\
\text { and health associate professionals; Teaching } \\
\text { associate professionals; Other associate } \\
\text { professionals; Customer services clerks; } \\
\text { Personal and protective services workers; } \\
\text { Models, salespersons, and demonstrators; } \\
\text { Skilled agricultural and fishery workers; } \\
\text { Extraction and building trades workers; } \\
\text { Metal, machinery, and related trades work- } \\
\text { ers; Precision, handicraft, craft printing } \\
\text { and related trades workers; Other craft and } \\
\text { related trades workers; Stationary plant } \\
\text { and related operators; Machine operators } \\
\text { and assemblers; Drivers and mobile plant } \\
\text { operators; Sales and services elementary oc- } \\
\text { cupations; Agricultural, fishery, and related } \\
\text { labourers; Labourers in mining, construc- } \\
\text { tion, manufacturing, and transport (refer- } \\
\text { ence: office clerks) }\end{array}$ \\
\hline Industry & $\begin{array}{l}17 \text { industry dummies based on NACE clas- } \\
\text { sification: farming, forestry, fishing; mining } \\
\text { etc.; manufacturing; energy and water } \\
\text { supply; construction; trading; hotel and } \\
\text { restaurant industry; traffic and transport; in- } \\
\text { surance; real estate; services for enterprises; } \\
\text { public sector; education; health and social; } \\
\text { private households; religion, culture and } \\
\text { sports; other services (reference: research } \\
\text { and databases) }\end{array}$ \\
\hline
\end{tabular}

Personal

Age $^{2} \quad=$ Age in years ${ }^{2} / 100$

Hobbies (h/weekday) Average hours spent for hobbies on a weekday

Marital status $\quad 5$ dummies for married and living separated, single, divorced, widowed, and partner abroad (reference: married and living together)

Partnership Dummy living in a partnership

Household

Household size $\quad 5$ dummies for $2,3,4,5$, and 6 or more person households (reference: single households)

Children 3 dummies for 1, 2, 3 or more children up to the age of 16 in household (reference: no children) 
Table 2 (Continued)

\begin{tabular}{|c|c|}
\hline Variable & Definition \\
\hline Mortgage & $\begin{array}{l}\text { Interest and mortgage payment per month } \\
\text { in } € / 1000\end{array}$ \\
\hline Rent & $\begin{array}{l}\text { Monthly rent excluding heating costs in } \\
€ / 1000\end{array}$ \\
\hline Owner & Owner of house or flat \\
\hline $\ln ($ residual income $)$ & $\begin{array}{l}\ln ((\text { household net income-personal } \\
\text { income }) \in / 1000)\end{array}$ \\
\hline \multicolumn{2}{|l|}{ Region } \\
\hline East Germany & Dummy variable \\
\hline $\begin{array}{l}\text { German federal } \\
\text { states }\end{array}$ & $\begin{array}{l}15 \text { dummies for German federal states: Ber- } \\
\text { lin, Schleswig-Holstein; Hamburg; Bremen; } \\
\text { North Rhine-Westphalia; Hessen; Rhineland- } \\
\text { Palatinate; Saarland; Baden-Wuerttemberg; } \\
\text { Bavaria; Mecklenburg-West Pomerania; } \\
\text { Brandenburg; Saxony-Anhalt; Thuringia; } \\
\text { Saxony (reference: Lower Saxony) }\end{array}$ \\
\hline Year & $\begin{array}{l}\text { Wave dummies for 1989-2005; (reference: } \\
\text { 1988) }\end{array}$ \\
\hline
\end{tabular}

Table 3 Descriptive statistics on main variables of estimation sample. (Source: Own calculations based on SOEP 1984-2009)

\begin{tabular}{lllll}
\hline & Mean & Std.dev. & Min. & Max. \\
\hline Job satisfaction & 7.130 & 1.851 & 0 & 10 \\
Self-employment & & & & \\
T-4 & 0.003 & 0.056 & 0 & 1 \\
T-3 & 0.004 & 0.060 & 0 & 1 \\
T-2 & 0.004 & 0.061 & 0 & 1 \\
T-1 & 0.004 & 0.061 & 0 & 1 \\
T & 0.003 & 0.055 & 0 & 1 \\
T+1 & 0.003 & 0.054 & 0 & 1 \\
T+2 & 0.003 & 0.054 & 0 & 1 \\
T+3 & 0.003 & 0.057 & 0 & 1 \\
T+4+ & 0.044 & 0.206 & 0 & 1 \\
General job changes (leads und lags) & & & \\
T-4 & 0.019 & 0.137 & 0 & 1 \\
T-3 & 0.022 & 0.146 & 0 & 1 \\
T-2 & 0.026 & 0.160 & 0 & 1 \\
T-1 & 0.035 & 0.183 & 0 & 1 \\
T & 0.037 & 0.188 & 0 & 1 \\
T+1 & 0.037 & 0.190 & 0 & 1 \\
T+2 & 0.039 & 0.193 & 0 & 1 \\
T+3 & 0.040 & 0.196 & 0 & 1 \\
T+4 & 0.056 & 0.229 & 0 & 1 \\
Job & & & & \\
ln(net income (earned)) & 7.213 & 0.528 & 3.219 & 9.638 \\
Experience (full-time, years) & 17.932 & 9.491 & 0 & 47 \\
Experience (part-time, years) & 1.925 & 4.506 & 0 & 41 \\
Experience (unemployment, years) & 0.281 & 0.884 & 0 & 24 \\
Activity is job & 0.587 & 0.492 & 0 & 1 \\
Working hours/week & 40.558 & 10.044 & 0.5 & 80 \\
Working hours $2 / 100$ & 17.458 & 8.169 & 0.003 & 64 \\
Prefers to work \# hours less & 5.119 & 7.004 & 0 & 70 \\
Prefers to work \# hours more & 0.799 & 3.152 & 0 & 51 \\
Part-time & 0.101 & 0.302 & 0 & 1 \\
Liberal profession & 0.015 & 0.120 & 0 & 1 \\
\hline & & & & \\
\hline
\end{tabular}

Tabel 4 Observations in different lead and lag situations before and after changing from employment to self-employment in the estimation sample. (Source: Own calculations based on SOEP 1984-2009)

\begin{tabular}{llllllllll}
\hline Self- & $\mathrm{T}-4$ & $\mathrm{~T}-3$ & $\mathrm{~T}-2$ & $\mathrm{~T}-1$ & $\mathrm{~T}$ & $\mathrm{~T}+1$ & $\mathrm{~T}+2$ & $\mathrm{~T}+3$ & $\mathrm{~T}+4+$
\end{tabular} employ-

ment

\begin{tabular}{llllllllll}
\hline All & 115 & 135 & 141 & 140 & 111 & 109 & 107 & 120 & 1647 \\
\hline
\end{tabular}

How to read the table: e.g. T-4: The sample includes 115 observations of individuals 4 years prior to the individuals' changes from being an employee to self-employment; $\mathrm{T}+4+$ : The sample includes 1647 observations of individuals 4 and more years after the individuals' changes to self-employment

Tabel 5 Fixed effects regression results-The effect of self-employment on job satisfaction with and without anticipation and adaptation effects. (Source: Own calculations based on SOEP 1984-2009)

\begin{tabular}{|c|c|c|c|c|}
\hline & $\mathrm{I}$ & II & III & IV \\
\hline \multicolumn{5}{|l|}{ Self-employment } \\
\hline $\begin{array}{l}\text { Self-employed } \\
\text { (dummy) }\end{array}$ & $\begin{array}{l}0.590^{* * *} \\
(3.40)\end{array}$ & & $\begin{array}{l}0.201 \\
(1.16)\end{array}$ & \\
\hline \multicolumn{5}{|l|}{ Self-employed } \\
\hline $\mathrm{T}-4$ & & $\begin{array}{l}0.115 \\
(0.63)\end{array}$ & & $\begin{array}{l}0.259 \\
(1.40)\end{array}$ \\
\hline $\mathrm{T}-3$ & & $\begin{array}{l}0.137 \\
(0.83)\end{array}$ & & $\begin{array}{l}0.385^{*} \\
(2.24)\end{array}$ \\
\hline $\mathrm{T}-2$ & & $\begin{array}{l}-0.021 \\
(-0.10)\end{array}$ & & $\begin{array}{l}0.370^{+} \\
(1.80)\end{array}$ \\
\hline $\mathrm{T}-1$ & & $\begin{array}{l}-0.307 \\
(-1.43)\end{array}$ & & $\begin{array}{l}0.411^{+} \\
(1.89)\end{array}$ \\
\hline $\mathrm{T}$ & & $\begin{array}{l}0.752^{* *} \\
(3.27)\end{array}$ & & $\begin{array}{l}0.656^{* *} \\
(2.82)\end{array}$ \\
\hline $\mathrm{T}+1$ & & $\begin{array}{l}0.575^{*} \\
(2.40)\end{array}$ & & $\begin{array}{l}0.518^{*} \\
(2.15)\end{array}$ \\
\hline $\mathrm{T}+2$ & & $\begin{array}{l}0.691^{* *} \\
(2.84)\end{array}$ & & $\begin{array}{l}0.660^{* *} \\
(2.70)\end{array}$ \\
\hline $\mathrm{T}+3$ & & $\begin{array}{l}0.391 \\
(1.55)\end{array}$ & & $\begin{array}{l}0.459^{+} \\
(1.83)\end{array}$ \\
\hline $\mathrm{T}+4$ or more & & $\begin{array}{l}0.147 \\
(0.63)\end{array}$ & & $\begin{array}{l}0.271 \\
(1.16)\end{array}$ \\
\hline \multicolumn{5}{|c|}{ Job change (lead and lag variables) } \\
\hline $\mathrm{T}-4$ & & & $\begin{array}{l}-0.302^{* * *} \\
(-4.37)\end{array}$ & $\begin{array}{l}-0.318^{* * *} \\
(-4.49)\end{array}$ \\
\hline $\mathrm{T}-3$ & & & $\begin{array}{l}-0.407^{* * *} \\
(-5.32)\end{array}$ & $\begin{array}{l}-0.436^{* * *} \\
(-5.54)\end{array}$ \\
\hline $\mathrm{T}-2$ & & & $\begin{array}{l}-0.587^{* * *} \\
(-7.90)\end{array}$ & $\begin{array}{l}-0.610^{* * *} \\
(-7.96)\end{array}$ \\
\hline $\mathrm{T}-1$ & & & $\begin{array}{l}-1.111^{* * *} \\
(-14.89)\end{array}$ & $\begin{array}{l}-1.135^{* * *} \\
(-14.98)\end{array}$ \\
\hline $\mathrm{T}$ & & & $\begin{array}{l}0.349^{* * *} \\
(5.20)\end{array}$ & $\begin{array}{l}0.323^{* * *} \\
(4.73)\end{array}$ \\
\hline $\mathrm{T}+1$ & & & $\begin{array}{l}0.199^{* *} \\
(3.23)\end{array}$ & $\begin{array}{l}0.179^{* *} \\
(2.84)\end{array}$ \\
\hline $\mathrm{T}+2$ & & & $\begin{array}{l}0.198^{* * *} \\
(3.57)\end{array}$ & $\begin{array}{l}0.172^{* *} \\
(3.02)\end{array}$ \\
\hline $\mathrm{T}+3$ & & & $\begin{array}{l}0.064 \\
(1.27)\end{array}$ & $\begin{array}{l}0.051 \\
(0.99)\end{array}$ \\
\hline
\end{tabular}


Tabel 5 (Continued)

\begin{tabular}{|c|c|c|c|c|}
\hline & I & II & III & IV \\
\hline $\mathrm{T}+4$ or more & & & $\begin{array}{l}0.064 \\
(1.62)\end{array}$ & $\begin{array}{l}0.064 \\
(1.62)\end{array}$ \\
\hline \multicolumn{5}{|l|}{ Job } \\
\hline $\begin{array}{l}\ln (\text { net income } \\
\text { (earned)) }\end{array}$ & $\begin{array}{l}0.516^{* * *} \\
(7.78)\end{array}$ & $\begin{array}{l}0.519^{* * *} \\
(7.84)\end{array}$ & $\begin{array}{l}0.459^{* * *} \\
(7.13)\end{array}$ & $\begin{array}{l}0.459^{* * *} \\
(7.14)\end{array}$ \\
\hline $\begin{array}{l}\text { Experience (full- } \\
\text { time. years) }\end{array}$ & $\begin{array}{l}-0.115 \\
(-1.28)\end{array}$ & $\begin{array}{l}-0.115 \\
(-1.28)\end{array}$ & $\begin{array}{l}-0.110 \\
(-1.23)\end{array}$ & $\begin{array}{l}-0.112 \\
(-1.25)\end{array}$ \\
\hline $\begin{array}{l}\text { Experience (part- } \\
\text { time. years) }\end{array}$ & $\begin{array}{l}-0.099 \\
(-1.09)\end{array}$ & $\begin{array}{l}-0.010 \\
(-1.10)\end{array}$ & $\begin{array}{l}-0.094 \\
(-1.04)\end{array}$ & $\begin{array}{l}-0.097 \\
(-1.07)\end{array}$ \\
\hline $\begin{array}{l}\text { Experience (unem- } \\
\text { ployment. years) }\end{array}$ & $\begin{array}{l}0.322 \\
(1.64)\end{array}$ & $\begin{array}{l}0.318 \\
(1.62)\end{array}$ & $\begin{array}{l}0.058 \\
(0.32)\end{array}$ & $\begin{array}{l}0.051 \\
(0.28)\end{array}$ \\
\hline Activity is job & $\begin{array}{l}0.026 \\
(0.66)\end{array}$ & $\begin{array}{l}0.027 \\
(0.69)\end{array}$ & $\begin{array}{l}0.039 \\
(1.02)\end{array}$ & $\begin{array}{l}0.040 \\
(1.05)\end{array}$ \\
\hline $\begin{array}{l}\text { Working hours/ } \\
\text { week }\end{array}$ & $\begin{array}{l}-0.010 \\
(-1.14)\end{array}$ & $\begin{array}{l}-0.010 \\
(-1.11)\end{array}$ & $\begin{array}{l}-0.010 \\
(-1.21)\end{array}$ & $\begin{array}{l}-0.010 \\
(-1.18)\end{array}$ \\
\hline Working hours $2 / 100$ & $\begin{array}{l}0.015 \\
(1.54)\end{array}$ & $\begin{array}{l}0.015 \\
(1.51)\end{array}$ & $\begin{array}{l}0.015 \\
(1.59)\end{array}$ & $\begin{array}{l}0.015 \\
(1.56)\end{array}$ \\
\hline $\begin{array}{l}\text { Prefers to work \# } \\
\text { hours less }\end{array}$ & $\begin{array}{l}-0.013^{* * *} \\
(-6.21)\end{array}$ & $\begin{array}{l}-0.013^{* * *} \\
(-6.20)\end{array}$ & $\begin{array}{l}-0.013^{* * *} \\
(-6.31)\end{array}$ & $\begin{array}{l}-0.013^{* * *} \\
(-6.28)\end{array}$ \\
\hline $\begin{array}{l}\text { Prefers to work \# } \\
\text { hours more }\end{array}$ & $\begin{array}{l}-0.018^{* * *} \\
(-4.52)\end{array}$ & $\begin{array}{l}-0.018^{* * *} \\
(-4.52)\end{array}$ & $\begin{array}{l}-0.018^{* * *} \\
(-4.53)\end{array}$ & $\begin{array}{l}-0.018^{* * *} \\
(-4.54)\end{array}$ \\
\hline Part-time & $\begin{array}{l}0.058 \\
(0.66)\end{array}$ & $\begin{array}{l}0.060 \\
(0.69)\end{array}$ & $\begin{array}{l}0.060 \\
(0.70)\end{array}$ & $\begin{array}{l}0.061 \\
(0.72)\end{array}$ \\
\hline Liberal professions & $\begin{array}{l}0.206 \\
(1.39)\end{array}$ & $\begin{array}{l}0.202 \\
(1.37)\end{array}$ & $\begin{array}{l}0.240^{+} \\
(1.65)\end{array}$ & $\begin{array}{l}0.249^{+} \\
(1.72)\end{array}$ \\
\hline \multicolumn{5}{|c|}{ Controls (for details see Appendix 1) } \\
\hline $\begin{array}{l}\text { Occupation and } \\
\text { industry }\end{array}$ & $\sqrt{ }$ & $\sqrt{ }$ & $\sqrt{ }$ & $\sqrt{ }$ \\
\hline $\begin{array}{l}\text { Person and } \\
\text { household }\end{array}$ & $\sqrt{ }$ & $\sqrt{ }$ & $\sqrt{ }$ & $\sqrt{ }$ \\
\hline Region & $\sqrt{ }$ & $\sqrt{ }$ & $\sqrt{ }$ & $\sqrt{ }$ \\
\hline Years & $\sqrt{ }$ & $\sqrt{ }$ & $\sqrt{ }$ & $\sqrt{ }$ \\
\hline$R^{2}$ within & 0.0277 & 0.0286 & 0.0487 & 0.0492 \\
\hline $\begin{array}{l}\text { Min. observations/ } \\
\text { individual\# }\end{array}$ & 2 & 2 & 2 & 2 \\
\hline $\begin{array}{l}\text { Max. observations/ } \\
\text { individual }\end{array}$ & 17 & 17 & 17 & 17 \\
\hline $\begin{array}{l}\text { Mean observations/ } \\
\text { individual }\end{array}$ & 5.727 & 5.727 & 5.727 & 5.727 \\
\hline Individuals & 6488 & 6488 & 6488 & 6488 \\
\hline Observations & 37,158 & 37,158 & 37,158 & 37,158 \\
\hline
\end{tabular}

t-Statistics based on robust standard errors in parentheses; sample: age 15-64; \# To be read as: For an individual with 2 observations we could use 2 years. For each of these 2 years we additionally considered information about the same individual 4 years before and afterwards. A minimum of 2 observations per individual therefore encompass 2 times $9=18$ observations

${ }^{+} p<0.10 ;{ }^{*} p<0.05 ; * * p<0.01 ; * * * p<0.001$

\section{References}

Arvey, R.D., Bochard, T.J., Segal, N.L., Abraham, L.M.: Job satisfaction-Environmental and genetic components. J. Appl. Psychol. 74(2), 187-192 (1989)

Ashenfelter, O.: Estimating the effect of training programs on earnings. Rev. Econ. Stat. 60(1), 47-57 (1978)
Benz, M., Frey, B.: Being independent raises happiness at work. Swedish Econ. Pol. Rev. 11(2), 95-134 (2004)

Benz, M., Frey, B.: Being independent is a great thing-Subjective evaluations of self-employment and hierarchy. Economica. 75(298), 362-383 (2008)

Binder, M., Coad, A.: Life satisfaction and self-employment-A matching approach. Small Bus. Econ. (2012). doi: 10.1007/ s11187-011-9413-9

Blanchflower, D.G.: Self-employment in OECD countries. Lab. Econ. 7(5), 471-505 (2000)

Blanchflower, D.G., Oswald, A.J.: What makes an entrepreneur? J. Lab. Econ. 16(1), 26-60 (1998)

Blanchflower, D.G., Oswald, A.J., Stutzer, A.: Latent entrepreneurship across nations. Europ. Econ. Rev. 45, 680-691 (2001)

Brickman, P., Campbell, D.T.: Hedonic relativism and planning the good society. In: Appley, M. (ed.) Adaptation Level tTheory-A Symposium, pp. 287-302. Academic Press, New York (1971)

Brockhaus, R.H., Horwitz, P.S.: The psychology of entrepreneur. In: Sexton, D.L., Smilor, R.W. (eds.) The Art of Science of Entrepreneurship, pp. 25-48. Ballinger, Massachusetts (1986)

Caliendo, M., Fossen, F., Kritikos, A.S.: Personality characteristics and the decision to become and stay self-employed. Small Bus. Econ. 42(4), 787-814 (2014)

Carrington, W., McCue, K., Pierce, B.: The role of employer/employee interactions in labor market cycles-Evidence from the self-employed. J. Lab. Econ. 14(4), 571-602 (1996)

Clark, A.E., Georgellis, Y.: Back to Baseline in Britain- Adaption in the BHPS, IZA Discussion Paper No. 6426, Bonn 2012

Clark, A.E., Senik, C.: The (unexpected) structure of "rents" on the French and British labour markets. J. Socio-Econ. 35(2), 180-196 (2006)

Clark, A.E., Diener, E., Georgellis, Y., Lucas, R.E.: Lags and leads in life satisfaction-A test of the baseline hypothesis. Econ. J. 118(529), 222-243 (2008)

De Neve, J.-E., Fowler, J.H., Frey, B.S.: Genes, Economics, and Happiness, University of Zurich-Institute for Empirical Research in Economics, Working Paper Series No. 475, Zürich 2010

Diener, E., Lucas, R.E., Scollon, N.: Beyond the hedonic treadmillRevising the adaptation theory of well-being. Am. Psychol. 61(4), 305-314 (2006)

Eden, D.: Organizational membership vs self-employment-Another blow to the American dream. Organ. Behav. Human Perform. 13(1), 79-94 (1975)

Ferrer-i-Carbonell, A., Frijters, P.: How important is methodology for the estimates of determinants of happiness? Econ. J. 114(497), 641-659 (2004)

Frederick, S., Loewenstein, G.: Hedonic adaptation. In: Diener, E., Kahneman, D., Schwarz, N. (eds.) Well-being-The foundations of hedonic psychology, pp. 302-329. Russell Sage Foundation, New York (1999)

Frijters, P., Johnston, D.W., Shields, M.A.: Life satisfaction dynamics with quarterly life event data. Scandinavian J. Econ. 113(1), 190-211 (2011)

Greene, W.H.: The Bias of the Fixed Effects Estimator in Nonlinear Models, NYU Working Paper No. EC-02-05 2002

Greene, W.H., Hensher, D.A.: Modeling Ordered Choices-A Primer. Cambridge University Press, Cambridge (2010)

Hamermesh, D.S.: Subjective outcomes in economics-Association lecture. Southern Econ. J. 71(1), 2-11 (2004)

Hamilton, B.H.: Does entrepreneurship pay? An empirical analysis of the returns to self-employment. J. Polit. Economy. 108(3), 604$631(2000)$

Hanglberger, D.: Arbeitszufriedenheit im internationalen Vergleich, FFB-Diskussionspapiere, No. 86. Leuphana University Lüneburg, Lüneburg (2011a) 
Hanglberger, D.: Does job satisfaction adapt to working conditions? An empirical analysis for rotating shift work, flextime, and temporary employment in UK, FFB-Discussion Papers, No. 87. Leuphana University Lüneburg, Lüneburg (2011b)

Hanglberger, D.: Arbeitszufriedenheit und Flexibilität-Europäischer Vergleich und Adaptions- und Antizipationseffekte, FFB-Schriftenreihe, Bd. 21. Nomos, Baden-Baden (2013)

Heckman, J.J., Lalonde, R.J., Smith, J.A.: The economics and econometrics of active labor market programs. In: Ashenfelter, O., Card, D. (eds.) Handbook of Labour Economics,3, pp. 1865-2097. Elsevier, Amsterdam (1999)

Hundley, G.: Why and when are the self-employed more satisfied with their work? Ind. Relat. 40(2), 293-316 (2001)

Hyytinen, A., Ruuskanen, O.P.: Time use of the self-employed. Kyklos. 60(1), 105-122 (2007)

Kawaguchi, D.: Self-employment rents-Evidence from job satisfaction scores. Hitotsubashi J. Econ. 49(1), 35-45 (2008)

Landsberger, H.A.: Hawthorne Revisited. Ithaca, The New York State Schoolof Industrial and Labor Relations (1958)

Levy-Garboua, L., Montmarquette, C., Simonnet, V.: Job satisfaction and quits. Lab. Econ. 14(2), 251-268 (2007)

Long, S.: Regression Models for Categorical and Limited Dependent Variables. Sage Publications, Thousand Oaks (1997)

Lucas, R.E.: Time does not heal all wounds - A longitudinal study of reaction and adaptation to divorce. Psychol Sci. 16(12), 945-950 (2005)

Lykken, D., Tellegen, A.: Happiness is a stochastic phenomenon. Psychol Sci. 7(3), 186-189 (1996)

McKelvey, R.D., Zavoina, W.: A statistical model for the analysis of ordinal level dependent variables. J. Math. Sociol. 4, 103-120 (1975)

Merz, J.: (2007): Polarisierung der Einkommen von Selbständigen?Zur Dynamik der Einkommensverteilung von Freiberuflern und Unternehmern, in: Merz, J. (Ed.), Fortschritte der MittelstandsForschung, Merz J., Schulte R. and J. Wagner (Series Eds.), Entrepreneurship, Professions, Small Business Economics, CREPS-Schriftenreihe, Vol. 3, LIT Publisher, Münster, 395-415

Merz, J., Böhm, P.: Tägliche Arbeitszeitmuster und Einkommen von Freien Berufen - Neue Ergebnisse auf der Basis von Zeittagebüchern. In: Merz, J. (ed.) Freie Berufe - Einkommen und Steuern (FB€St) - Beiträge aus Wissenschaft, Praxis und Politik, pp. 93118. Nomos Verlagsgesellschaft, Baden-Baden (2008)

Merz, J., Burgert, D.: Arbeitszeitarrangements-Neue Ergebnisse aus der Zeitbudgeterhebung 2001/02 im Zeitvergleich zu 1991/92. In: Schäfer, D. (ed.) Alltag in Deutschland-Analysen zur Zeitverwendung, pp. 304-336. Statistisches Bundesamt, Wiesbaden (2004a)

Merz, J., Burgert, D.: Wer arbeitet wann? Arbeitszeitarrangements von Selbständigen und abhängig Beschäftigten-Eine mikroökonometrische Analyse deutscher Zeitbudgetdaten. In: Merz, J., Wagner, J. (eds.) Perspektiven der MittelstandsForschung- Ökonomische Analysen zu Selbständigkeit, Freien Berufen und KMU, pp. 303330. Lit-Verlag, Münster (2004b)
Merz, J., Böhm, P., Burgert, D.: Timing and fragmentation of daily working hours arrangements and income inequality-An earnings treatment effects approach with german time use diary data. Electron. Int. J. Time Use Res,. 6(2), 200-239 (2009)

Millán, J.M., Hessels, J., Thurik, R., Aguado, R.: Determinants of job satisfaction: A European comparison of self-employed and paid employees. Small Bus. Econ. (2011). doi:10.1007/ a11187-011-9380-1

Oswald, A.J., Powdthavee, N.: Does happiness adapt? - A longitudinal study of disability with implications for economists and judges. J. Public Econ. 92, 1061-1077 (2008)

Parker, S.C.: The Economics of Entrepreneurship. Cambridge University Press, Cambridge (2009)

Powdthavee, N.: Anticipation, free-rider problem, and adaptation to trade union-Re-examining the curious case of dissatisfied union members. Ind. Labor Relat. Rev. 64(5), 1000-1019 (2011)

Siegel, N.A., Huber, S., Gensicke, A., Geue, D., Stimmel, S., Stutz, F.: SOEP 2009 Methodenbericht zum Befragungsjahr 2009 (Welle 26) des Sozio-oekonomischen Panels, München (2010)

van Praag, B., Ferrer-I-Carbonell, A.: (2008): Happiness Quantified, A Satisfaction Calculus Approach, Oxford

Wagner, G.G., Frick, J.R., Schupp, J.: The german socio-economic panel study (SOEP)-Scope, evolution and enhancements. J. Appl. Soc. Sci. Stud. 127(1), 139-179 (2007)

Zhao, H., Seibert, S.E.: The big five personality dimensions and entrepreneurial status: A meta-analytical review. J. Appl. Psychol. 91(2), 259-271 (2006)

Dominik Hanglberger currently holds the position of a research associate at the "Institut des Bewertungsausschusses". From 2006 till 2011 he was working at the Research Institute on Professions (FFB) of the Leuphana University of Lueneburg. His research focuses on models for limited dependent variables, applied empirical micro-economics and subjective well-being. He earned his doctorate at the Leuphana University of Lueneburg with a dissertation on the job satisfaction and flexibility.

Joachim Merz Dr. rer. pol. and University Professor (Economics and Econometrics), is currently Director of the 'Research Institute on Professions (FFB)' of the Leuphana University Lüneburg. He is interested in microanalyses based on microeconomic theory, microeconometrics and microsimulation of policy impacts; Recent fields: welfare economics: income and income distribution, poverty and richness, polarization, time-use and economic well-being, labour market, economic and social policy with emphasis on professions, self-employed and employees. 